\title{
TP53 NP_000537.3:p.Y220C
}

National Cancer Institute

\section{Source}

National Cancer Institute. TP53 NP 000537.3:p.Y220C. NCI Thesaurus. Code C146890.

A change in the amino acid residue at position 220 in the cellular tumor antigen p53

protein where tyrosine has been replaced by cysteine. 